medRxiv preprint doi: https://doi.org/10.1101/2020.11.03.20225268; this version posted November 4, 2020. The copyright holder for this preprint (which was not certified by peer review) is the author/funder, who has granted medRxiv a license to display the preprint in

It is made available under a CC-BY-NC-ND 4.0 International license.

\title{
Test-adjusted results of mortality for Covid-19 in Germany, USA, UK
}

Jürgen Mimkes ${ }^{1}$ and Rainer Janssen ${ }^{2}$

\section{Abstract}

In a disease, where all infected persons show symptoms, it is reasonable to calculate mortality by case to fatality rate CFR. Deaths follow infections by a certain time lag. However, in the Covid-19 pandemic many infectious patients show no or hardly any symptoms. The reported infections and deaths do not run parallel, but diverge with the volume of tests.

Our investigations for Germany, USA and UK indicate that deaths do not follow the number of infections, but the positive rate of tests, multiplied by a constant factor $F$ and shifted by about two weeks. These test adjusted results of mortality allow for the estimation of the number of deaths of Covid-19 about two weeks ahead, even in a sharply rising state of the pandemic. This gives medical authorities two weeks of time to plan for resources.

\section{Introduction}

Mortality is the most important indicator of a pandemic and scientists all over the world are estimating mortality from Covid-19. A good introduction has been given in a scientific brief by the World Health Organization WHO [1]. In a pandemic, two time series are generally reported: the time series of daily infections $\left(I_{k}\right)$, and the time series for daily deaths $\left(D_{k}\right)$, as provided by the Johns-Hopkins-University (JHU) in USA and the Robert-Koch-Institute (RKI) in Germany. A wide range of values has been reported in the literature for the CFR, varying with time and location [2-4]. In this paper we concentrate on mortality in Germany, USA, and UK.

\section{The RKI data for Germany}

The series of daily registered new infections $\left(I_{k}\right)$ and the series of daily deaths $\left(D_{k}\right)$ are given in figs. 1 and 2.

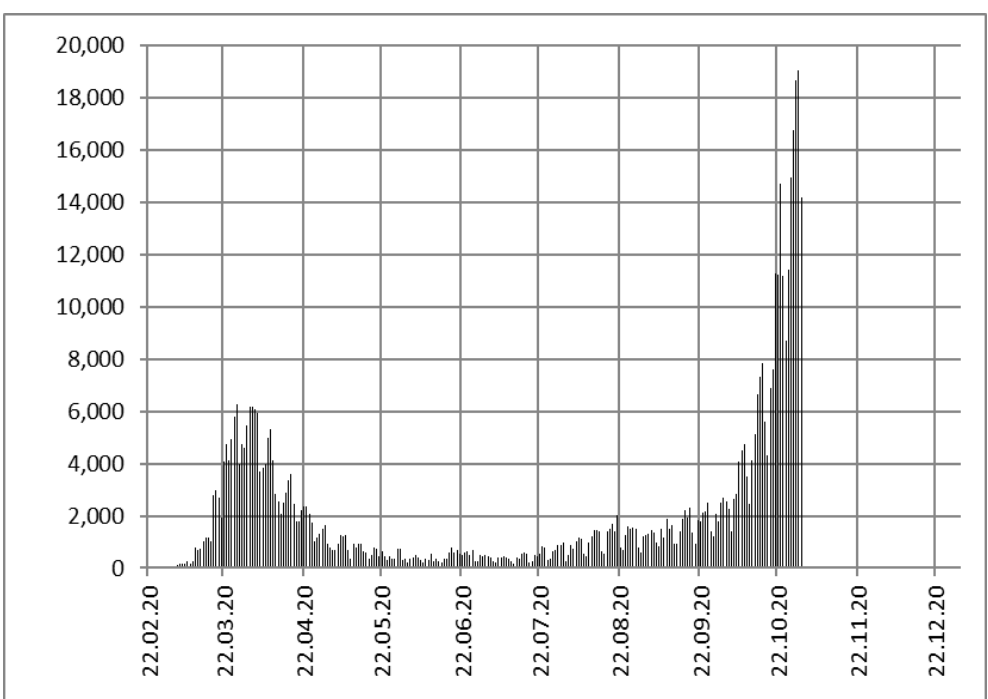

Fig. 1. Daily new infections I $k$ in Germany (RKI)

NOTE: This preprint reports new research that has not been certified by peer review and should not be used to guide clinical practice.

${ }_{1}^{1}$ Prof. ret. Dr. Juergen Mimkes, Physics Department, University Paderborn, Germany

2 Dr. Rainer Janssen, Engineering Office, Paderborn, Germany 
medRxiv preprint doi: https://doi.org/10.1101/2020.11.03.20225268; this version posted November 4, 2020. The copyright holder for this preprint (which was not certified by peer review) is the author/funder, who has granted medRxiv a license to display the preprint in

It is made available under a CC-BY-NC-ND 4.0 International license .

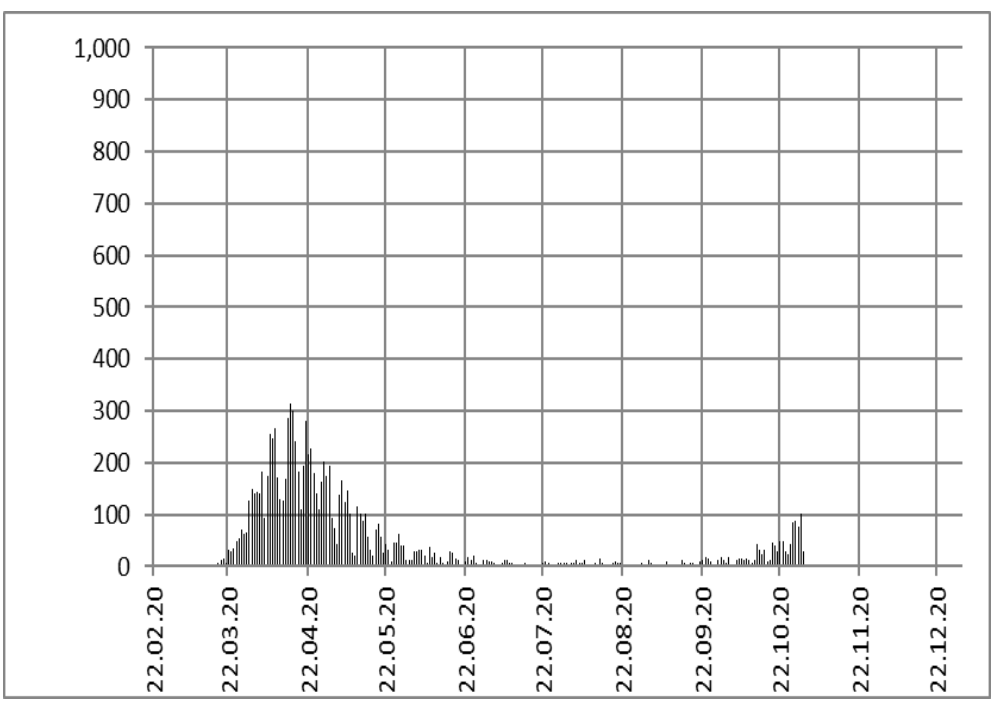

Fig. 2. Daily deaths $D_{k+13}$ in Germany (RKI)

\section{Calculation of CFR mortality}

Normally, in mortality calculations the series of daily deaths $\left(D_{k+L}\right)$ follows the series of daily infections $\left(I_{k}\right)$ by a time lag $(L)$ and is smaller by the case fatality ratio CFR,

$$
D_{k+L}=C F R * I k .
$$

In fig. 2 the maximum of deaths (300) follows the maximum of infected (6000) in fig. 1 about two weeks $(L=13)$ later, and is smaller by the factor $C F R=300 / 6000=0.05$. This leads to

$$
D_{k+13}=0.05 * I_{k}
$$

Eq. (2) has been plotted in fig. 3.

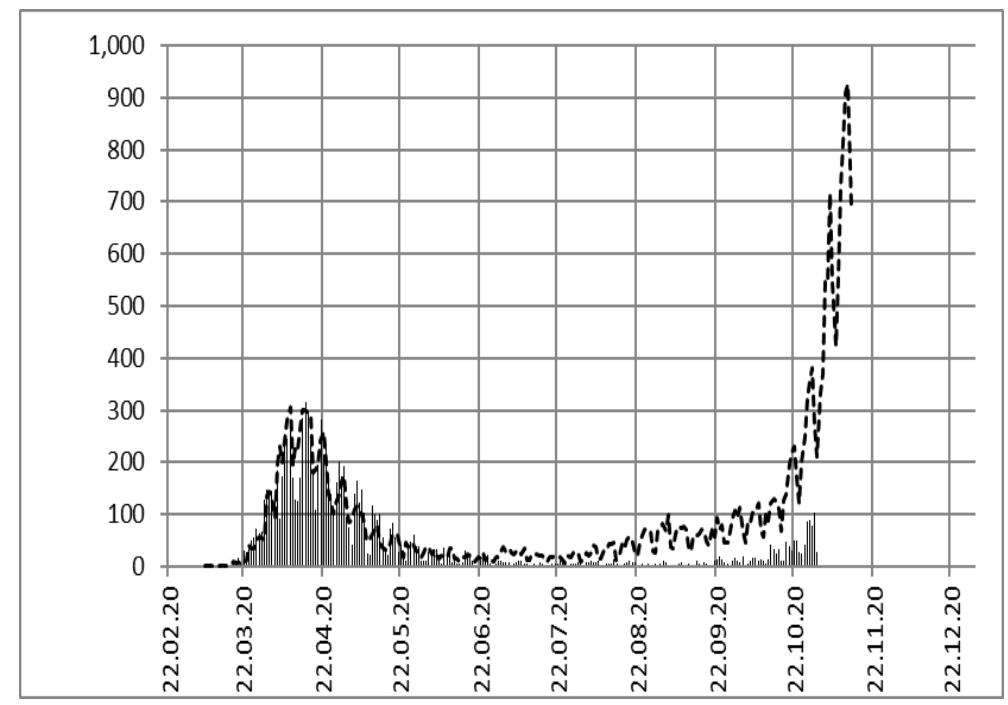

Fig. 3. Daily deaths data by RKI (bars) and calculation of $D_{k+13}$ according to eq. (2) (dotted line).

Data and calculation of CFR mortality in fig. 3 agree for the first Covid-19 wave from March to June, as would be expected. But from July on the calculations of daily deaths drifts away to higher numbers, whereas the actual death data stay close to zero between July and September, indicating only rising numbers in October. As the deaths in fig. 3 do not follow 
medRxiv preprint doi: https://doi.org/10.1101/2020.11.03.20225268; this version posted November 4, 2020. The copyright holder for this preprint (which was not certified by peer review) is the author/funder, who has granted medRxiv a license to display the preprint in

It is made available under a CC-BY-NC-ND 4.0 International license .

the infections, the CFR is not any more constant, but is time variant, CFR k. A similar observation has been made in many countries, as shown for USA and UK, below. In a recent paper the authors $[5,6]$ proposed to explain the disagreement between calculations (eq. 1) and mortal data in fig. 3 by considering a change in test volume. Indeed, the test volume in fig. 4 in Germany has been increased from July until September by a factor of 3 .

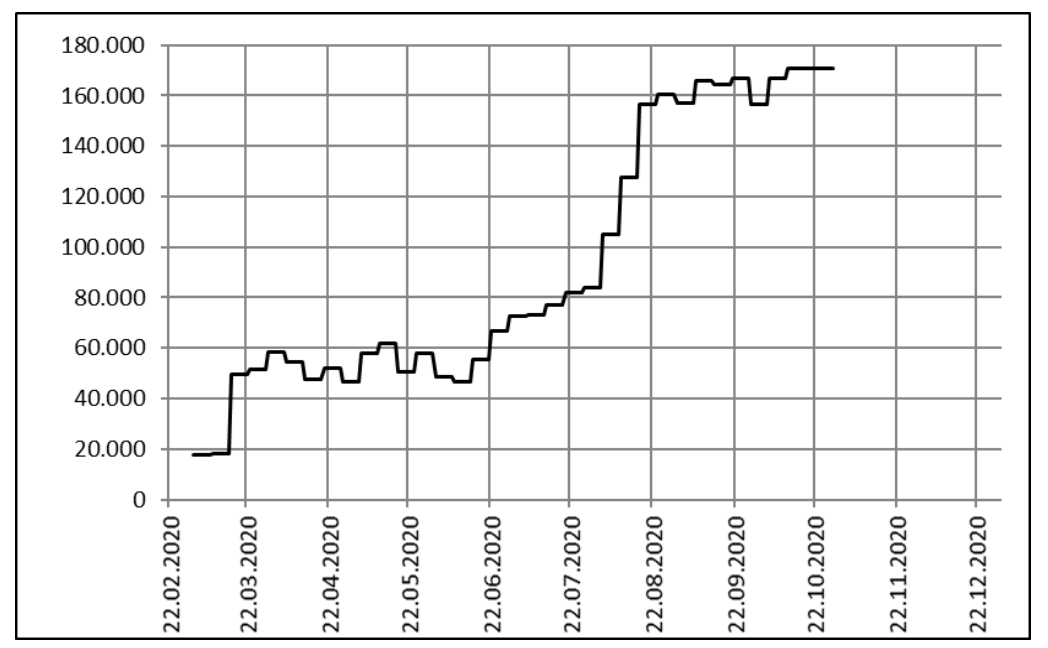

Fig. 4. Daily test volume $T_{k}$ (weekly reports by RKI)

For a more detailed analysis, we divide the infection numbers $\mathrm{I}$ by the test volume $T_{\mathrm{k}}$. Then we scale the result by a mortality factor $F=2500$ to obtain an optimal approximation to the deaths series of the pandemic in fig. 5 .

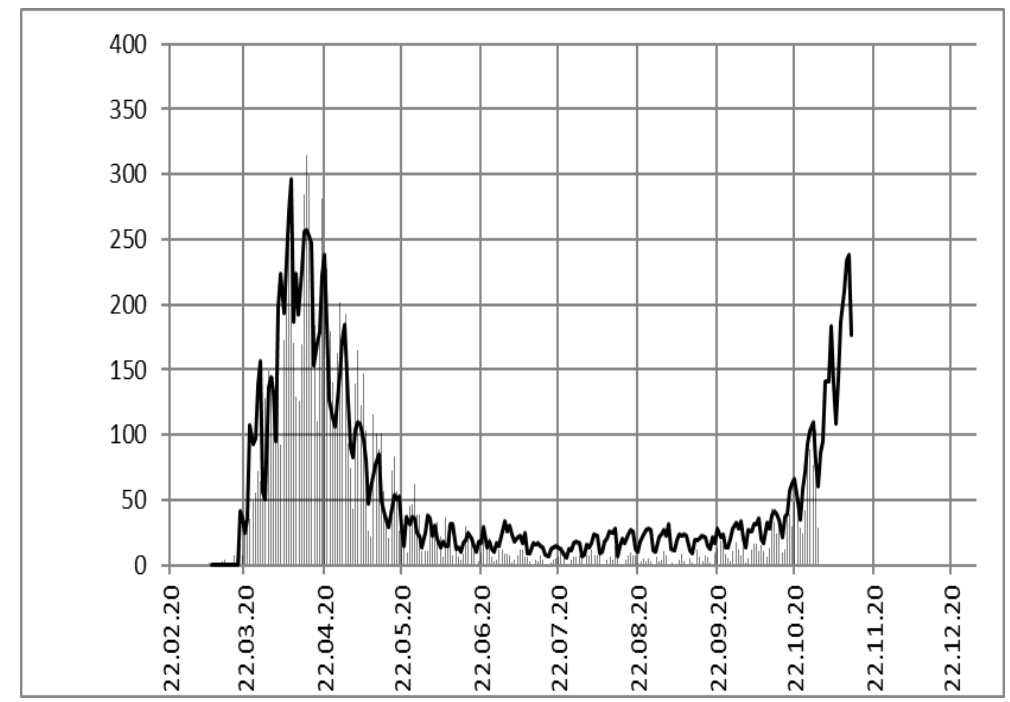

Fig. 5. Daily deaths data from RKI (bars) and infection numbers divided by test volume (solid line).

Apparently, in fig. 5 (solid line) the test adjusted infection data $\left(I_{k} / T_{k}\right)$ are in good agreement with the deaths data (bars) throughout the pandemic,

$$
D_{k+L}=F^{*} I_{k} / T_{k}=\left(2500 / T_{k}\right) * I_{k}=C F R_{k} * I_{k}
$$

and we obtain a test depending mortality $\mathrm{CFR}_{k}=2500 / \mathrm{T}_{\mathrm{k}}$. 
medRxiv preprint doi: https://doi.org/10.1101/2020.11.03.20225268; this version posted November 4, 2020. The copyright holder for this preprint (which was not certified by peer review) is the author/funder, who has granted medRxiv a license to display the preprint in

It is made available under a CC-BY-NC-ND 4.0 International license.

\section{A test adjusted approach to mortality}

In order to explain the test depending mortality CFR $\mathrm{k}$ in eq. 3 and fig. 5 , we propose a test adjusted approach to mortality: In diseases where many infectious patients show no or hardly any symptoms, we do not know the total number of infections. But we can determine the daily number of infections $I_{k, T}$ by the positive rate $P_{k}$ of daily infections of a certain daily test volume $\mathrm{T}_{\mathrm{k}}$,

$$
I_{k, T}=P_{k} * T_{k}
$$

In eq. 3 we may now replace the ratio $\mathrm{I}_{\mathrm{k}} / \mathrm{T}_{\mathrm{k}}$ by the positive rate of tests $\mathrm{P}_{\mathrm{k}}$ of eq. 4 ,

$$
D_{k+L}=F^{*} P_{k}
$$

In eq. 5 and fig. 5 the number of daily deaths $D_{k+L}$ follows the daily positive rate $P_{k}$, and not the daily number of infections $I_{k}$ as in eq. 1 . The daily numbers of infections and deaths are now represented in eq. 4 and eq. 5 by the daily positive rate $P_{k}$ and the daily test volume $T_{k}$. The daily test volume $T_{k}$ and the daily positive rate of infections $P_{k}$ are given by the RobertKoch-Institute, in figs. 4 and 6 . The time lag $L$ between infection and death is about 13 days in Germany.



Fig. 6. Positive rate $P_{k}$ of daily tests (from weekly reports by RKI)

The relationship between the number of daily deaths and the number of daily infected in eq. (1) is invalid, if the daily test volume is not constant. High numbers of infected do not necessarily mean high number of deaths.

The number of deaths is only determined by the positive rate of daily infections $P_{k}$, multiplied by a constant mortality factor $F$.

This statement does not diminish the danger of Covid-19, but puts it on a scientific basis. Accordingly, the daily positive rate of tests should be published in addition to the presently dominating infection numbers, which are used for other purposes like tracking.

The daily positive ratio of tests leads to a realistic estimation of the number of deaths two weeks in advance in eqs. 3 or 5 and in fig. 5.

This gives medical authorities two weeks of time to plan ahead for the numbers of severely ill patients, which are closely related the number of deaths. 
medRxiv preprint doi: https://doi.org/10.1101/2020.11.03.20225268; this version posted November 4, 2020. The copyright holder for this preprint (which was not certified by peer review) is the author/funder, who has granted medRxiv a license to display the preprint in It is made available under a CC-BY-NC-ND 4.0 International license

\section{JHU data for USA}

For USA, the Johns-Hopkins-University (JHU) provides the series of daily registered new infections $\left(I_{k}\right)$ and the series of daily deaths $\left(D_{k}\right)$ in figs. 7 and 8 . The daily test series is shown in fig. 9.



Fig. 7. Daily new infections I ${ }_{k}$ in USA (JHU)

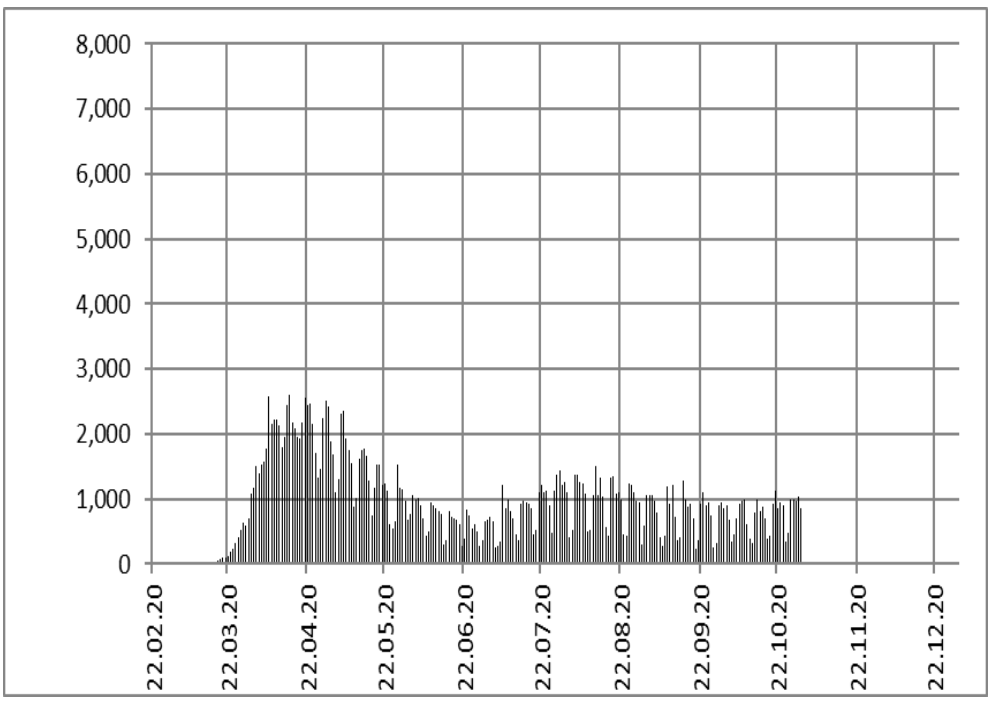

Fig. 8. Daily new deaths $D_{k+14}$ in USA (JHU) 
medRxiv preprint doi: https://doi.org/10.1101/2020.11.03.20225268; this version posted November 4, 2020. The copyright holder for this preprint (which was not certified by peer review) is the author/funder, who has granted medRxiv a license to display the preprint in

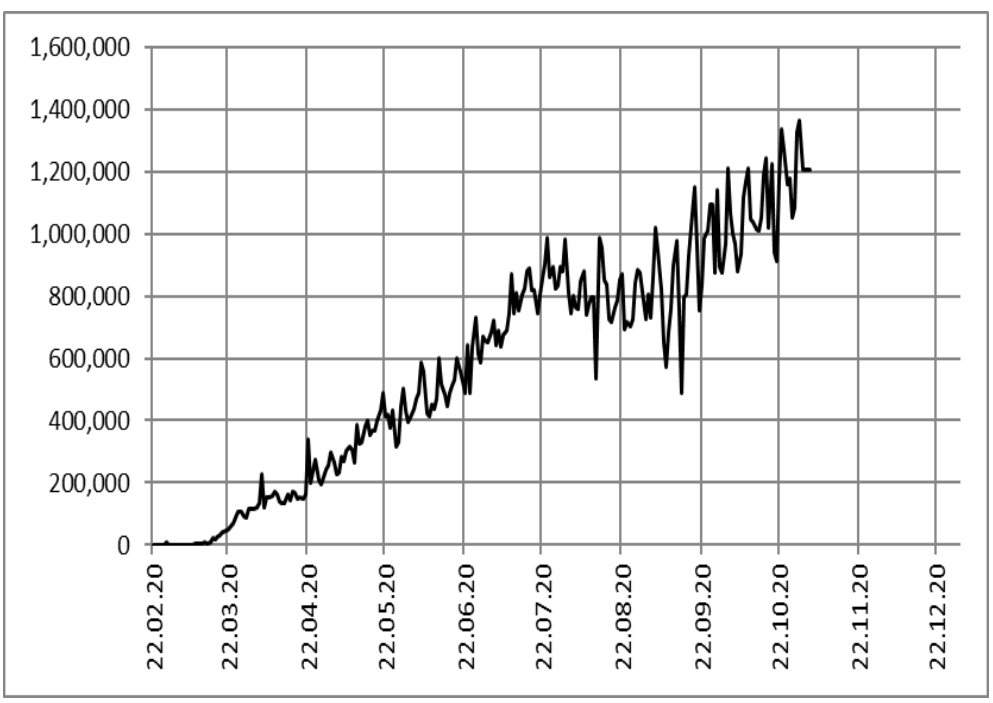

Fig. 9. Daily test volume $T_{k}$ in USA (The Covid Tracking Project [7])

Fig. 10 shows the calculation of the series of deaths $\left(D_{k+L}\right)$ according to eq. 1 by a dashed line and according to fig. 5 by a solid line.

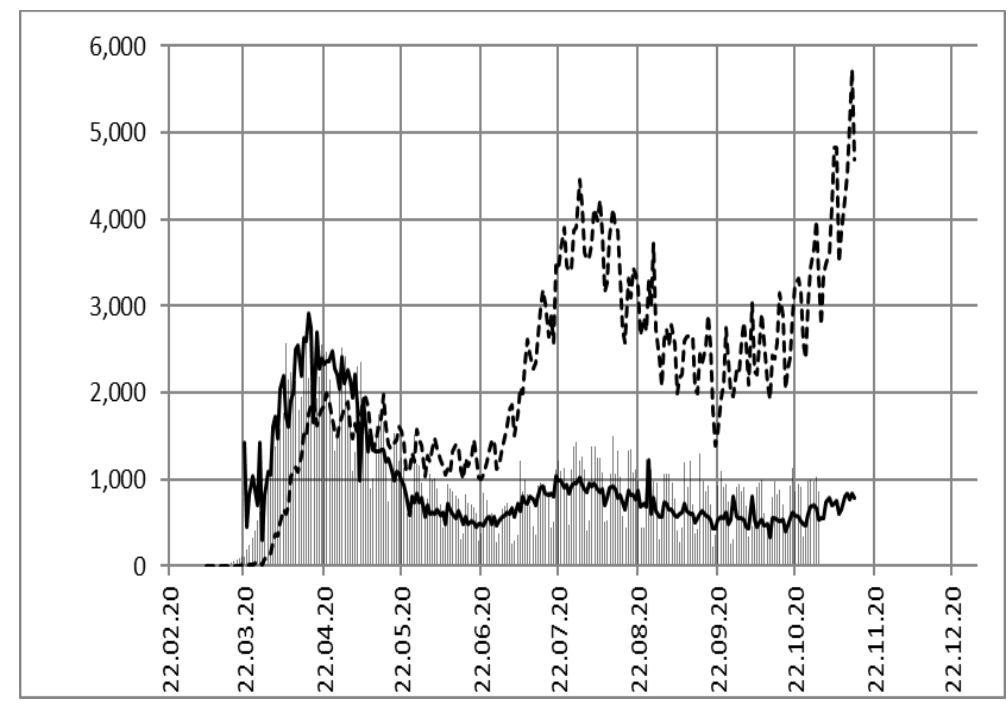

Fig. 10. Daily deaths data by JHU (bars) and calculation of $D_{k+14}$ according to eq. 1 (dashed line) and eq. 5 (solid line).

Fig 10 shows again a good agreement of the test adjusted infection data $\left(I_{k} / T_{k}\right)$ with the deaths data. The time lag $L$ is about 14 days and the mortality factor about $F$ USA $=11,500$. The mortality factor $F$ calculates the number of deaths of a country at a certain positive rate of testing $\left(P_{k}\right)$, accordingly, the mortality factor will depend on the population of a country if the modalities of testing are comparable.

Since the population in USA ( 320 million) is larger than the population in Germany ( 83 million) by a factor of about 4 , we would estimate $F$ USA $=4 * F_{\text {Ger }}=10,000$. This estimation is of the same order as the result above, and supports the test adjusted approach to mortality of Covid-19 in Germany and other countries. 
medRxiv preprint doi: https://doi.org/10.1101/2020.11.03.20225268; this version posted November 4, 2020. The copyright holder for this preprint (which was not certified by peer review) is the author/funder, who has granted medRxiv a license to display the preprint in It is made available under a CC-BY-NC-ND 4.0 International license.

\section{JHU data for UK}

In UK, the test adjusted infection data $\left(I_{k} / T_{k}\right)$ also lead to a realistic prediction of the death series of the Covid-19 pandemic (fig. 11). The time lag is about 14 days and the mortality factor $F$ uk about 2,700, deviating slightly from those in USA and Germany, if related to the population.

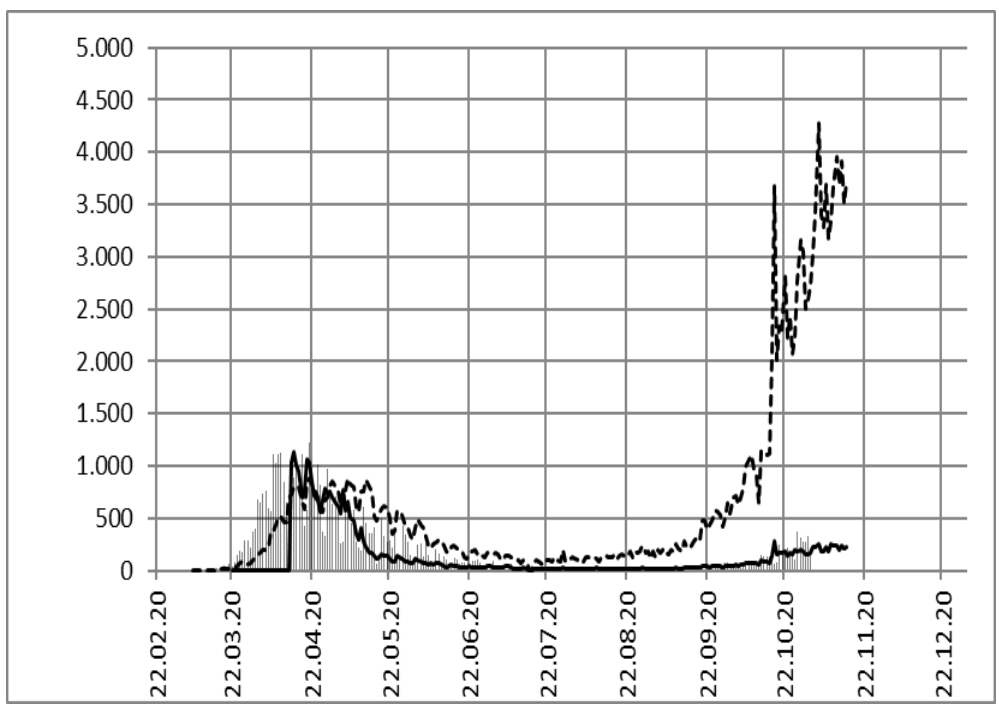

Fig. 11. Daily deaths data by JHU (bars) in UK and calculation of $D_{k+14}$ according to eq. 1 (dashed line) and eq. 5 (solid line). Test data since 31.03.20 [8].

\section{Conclusions}

In a pandemic with symptomatic and asymptomatic courses of the disease like in Covid-19, the pure number of infections is not significant for the danger of the pandemic. The indicator for the number of deaths is the positive rate $\left(P_{k}\right)$ of tests. It is a scale for the number of deaths, and in addition, it is known about two weeks earlier.

\section{References}

[1] WHO scientific brief August 4, 2020, Estimating mortality from COVID-19, https://www.who.int/publications/i/item/WHO-2019-nCoV-Sci-Brief-Mortality-2020.1

[2] Jing Li, Lishi Wang, Sumin Guo, Ning Xie, Lan Yao, Yanhong Cao, Sara W. Day, Scott C. Howard, J. Carolyn Graff, Tianshu Gu, Jiafu Ji, Weikuan Gu, Dianjun Sun, Real-time estimation and prediction of mortality caused by COVID-19 with patient information-based algorithm, Science of the total environment 727 (2020) 138394

[3] Andrew T Levin, William P. Hanage, Nana Owusu-Boaitey, Kensington B. Cochran, Seamus P. Walsh, Gideon Meyerowitz-Katz, ASSESSING THE AGE SPECIFICITY OF INFECTION FATALITY RATES FOR COVID-19: SYSTEMATIC REVIEW, META-ANALYSIS, AND PUBLIC POLICY IMPLICATIONS, https://www.medrxiv.org/content/10.1101/2020.07.23.20160895v7 
medRxiv preprint doi: https://doi.org/10.1101/2020.11.03.20225268; this version posted November 4, 2020. The copyright holder for this preprint (which was not certified by peer review) is the author/funder, who has granted medRxiv a license to display the preprint in It is made available under a CC-BY-NC-ND 4.0 International license .

[4] Johns-Hopkins-University (2020), https://raw.githubusercontent.com/CSSEGISandData/COVID-19/webdata/data/cases time.csv

[5] R. Janssen, J. Mimkes, Modeling numbers of infected and deceased - Adjustment by test volume, Webinar „COVID-19 Forecast and Prediction “, October 23, 2020, Karolinska Institutet, Stockholm, Sweden, https://physik.unipaderborn.de/fileadmin/physik/Alumni/Mimkes/2020-10-23-Test-normalized-infection$\underline{\text { numbers.pdf }}$

[6] J. Mimkes, R. Janssen, On the numbers of infected and deceased in the second Corona wave, https://www.medrxiv.org/content/10.1101/2020.08.10.20171553v1

[7] The Covid Tracking Project, https://covidtracking.com/data/national

[8] GOV.UK, Coronavirus (COVID-19) in the UK, https://coronavirus.data.gov.uk/testing 